\title{
O nadużyciach w badaniach nad doświadczeniem Zagłady
}

Piszemy w tym numerze o różnych postaciach kiczu dotykającego przedstawienia Zagłady w sztuce, w filmie, w literaturze. Jest to refleksja już dość dobrze zadomowiona we współczesnej humanistyce. Problematyka szeroko pojętych nadużyć w publicystycznej, literackiej i artystycznej reprezentacji Zagłady doczekała się błyskotliwych i gorzkich zarazem analiz dotyczących form obecności tego doświadczenia w przestrzeni publicznej. Wskazują one na rozrastające się niczym rak zjawisko makdonaldyzacji Holokaustu, jego politycznej instrumentalizacji, ideologicznej manipulacji i komercjalizacji (zob. klasyczne już prace Petera Novicka The Holocaust and Collective Memory. The American Experience, Toma Segeva The Seventh Million. The Israelis and the Holocaust czy Tima Cole'a Selling the Holocaust. From Auschwitz to Schindler. How History is Bought, Packaged, and Sold).

Sposoby ukazywania Zagłady w sztuce, filmie i literaturze poddawane są krytycznemu osądowi z perspektywy „etyki reprezentacji”, stosowności i niestosowności użytych środków wyrazu i przyjętego języka artystycznego. W bieżącym numerze zamieszczamy teksty Kingi Krzemińskiej o kiczu w kinie holokaustowym, Aleksandry Ubertowskiej o estetycznych manowcach literatury o Holokauście, Agnieszki Haskiej o patologii holokaustowego świadectwa, zastępującego pamięć konstrukcjami postpamięci, a opowieść o rzeczywistości doświadczonej - narracjami wyobraźni, wreszcie Anny Ziembińskiej-Witek o kiczu holokaustowym w muzeach. Wszystkie przywołane tu studia są niejako dalszym ciągiem toczącej się już dyskusji, dopowiadają, uzupełniają, rozwijają wątki wcześniej obecne. Spełniają też inną bardzo ważną rolę: zachęcają do spojrzenia na obszar, który zdecydowanie rzadziej bywa przedmiotem refleksji. Na różnego typu nadużycia w nauce o Zagładzie.

Chciałbym z tej możliwości skorzystać i podzielić się kilkoma refleksjami na ten temat. Będą to myśli uchwycone w biegu i zapisane na gorąco, raczej utrwalające stan niepokoju niż proponujące jakieś rozwiązanie czy diagnozę. To kilka myśli na tyle niegotowych, że nie powinny być uznane za uporządkowany opis sytuacji, ale na tyle nurtujących, że domagają się wypowiedzenia tu i teraz. 
Nie sposób zaprzeczyć, że to właśnie myśliciele postmodernistyczni uznali Zagładę za wydarzenie przełomowe, wyznaczające moment radykalnego załamania linii rozwojowej Zachodu. Z wielką mocą prezentują w swych tekstach przeświadczenie o kluczowej roli „ostatecznego rozwiązania” w doświadczeniu rodzaju ludzkiego epoki nowoczesnej. Dlatego Endlösung staje się jednym z głównych bohaterów postmodernistycznego dyskursu. $\mathrm{W}$ obrębie tych filozoficznych inspiracji wypracowane zostaje pojęcie Zagłady jako „wydarzenia granicznego” czy „zdarzenia skrajnego". Oznacza to, że wyniszczenie Żydów europejskich to nie tylko najskrajniejszy przypadek ludobójstwa w historii ludzkości, lecz także wydarzenie mające moc przekształcającą, w efekcie którego dochodzi do zburzenia podstaw dotychczasowego ładu cywilizacyjnego, a także do destrukcji wartości stanowiących jego fundament. Wydarzenie, które odsłania projekt nowoczesności i wskazując na jego przerażające implikacje, stawia go w stan oskarżenia. „Holokaust”, twierdzi Przemysław Czapliński, „to kamień nagrobny nowoczesności i płynny fundament ponowoczesności”'.

Według Jean-François Lyotarda ${ }^{2} \mathrm{w}$ komorach gazowych zgładzono nie tylko „rzeczywistość”, lecz także unicestwione zostały dotychczasowe sposoby mówienia o rzeczywistości. „Wielkie metanarracje”, ujmujące świat jako sensowną całość, legły w gruzach, ich miejsce zajął szereg „mikronarracji”: cząstkowych, tymczasowych, prowizorycznych, niegotowych. Nie ma już trwałego punktu oparcia, dotychczasowe reguły poznania zostały zniszczone, jesteśmy wrzuceni w sam środek konfliktu między różnymi porządkami „frazowania”, z których żaden nie ma ostatecznej i rozstrzygającej sankcji. Tę nieustanną walkę Lyotard nazywa poróżnieniem, sporem (francuskie différend, angielskie differend ${ }^{3}$ ) i czyni rdzeniem swojej koncepcji, którą formułuje w częstych odwołaniach do Zagłady. Auschwitz jest dla francuskiego filozofa synonimem destrukcji standardowych sposobów nazywania, osądzania, rozumienia. Auschwitz doprowadza do destrukcji także samo doświadczenie Auschwitz, ponieważ jest czymś tak radykalnie nowym w historii, że uniemożliwia nawet zaświadczenie o tym. Lyotard w swoim wywodzie odwołuje się do metafory potężnego trzęsienia ziemi, które niszczy wszystkie przyrządy sejsmograficzne, czyniąc odtąd niemożliwym jakikolwiek pomiar. Uczeni nie są w stanie zbadać i poznać tego, co się wydarzyło, a wśród zwykłych ludzi tworzy się „negatywny obraz nieokreślonego". Świadectwo o Auschwitz pozostaje czymś nie do pomyślenia, nie do wyrażenia. „Auschwitz”, pisze Lyotard, ,jest najbardziej rzeczywistą rzeczywistością. Jego nazwa wyznacza granice, w obrębie których wiedza historyczna dochodzi do zakwestionowania swoich kompetencji. Nie można już pójść dalej, ponieważ

${ }^{1}$ P. Czapliński, Zagłada jako wyzwanie dla refleksji o literaturze, „Teksty Drugie” 2004, nr 5, s. 11.

${ }^{2}$ The Differend: Phrases in Dispute, transl. G. Van Den Abbeele, Minneapolis 1996.

${ }^{3}$ Termin ten jest neologizmem. 
dojdzie się do nonsensu. Alternatywą nie jest albo sygnifikacja ustanawiana przez procedury poznawcze, albo absurd; jest nią rodzaj mistycyzmu"4.

Charakterystyczne, że Lyotard w swojej książce przywołuje nazwiska i dzieła wielkich filozofów od Platona i Arystotelesa, przez Kanta i Hegla, po Lévinasa, nie wspomina jednak ani słowem o takich wielkich świadkach Auschwitz jak Elie Wiesel, Charlotte Delbo, Primo Levi, Tadeusz Borowski, Imre Kertész. Prowadzi swój wywód niejako poza nimi, ponad ich głowami, tak jakby pozostawiał w czarnej dziurze wszystko to, co zdołało się stamtąd wydostać. Nie tylko świadectwa ocalonych pisane post factum, lecz także zagrzebane w popiołach krematorium w Birkenau rękopisy, ukrywane tam przez członków Sonderkommando z nadzieją, że ktoś je odnajdzie i będą czytane ${ }^{5}$.

Postmodernistyczny dyskurs o Zagładzie rodzi wiele niebezpieczeństw, a na prace części jego fundatorów - jak Maurice Blanchot czy Paul de Man - pada cień ich młodzieńczych związków z faszyzmem i antysemityzmem. Krytycy tego dyskursu wskazują między innymi na zagrożenie, jakie niesie zakwestionowanie faktu i statusu prawdy historycznej. Słusznie pisze Czapliński, że „nie ma takiego języka, który mógłby wyrazić prawdę Zagłady, ponieważ język niczego nie wyraża, a Zagłada nie ma swojej prawdy"6. Takie przeświadczenie może jednak łatwo stać się impulsem wyzwalającym bełkotliwą mowę kapłanów niewysłowionego lub być pożywką dla negacjonistów. Chociaż inni trzeźwo zwracają uwagę, że negacjoniści nie odwołują się do traktatów postmodernistycznych, lecz do swoiście interpretowanej empirii, to jednak warto posłuchać, co ma na ten temat do powiedzenia krytyk kultury Michiko Kakutani: „Rzecz w tym, że dekonstrukcja dostarcza błyskotliwie nihilistycznego widzenia świata, według którego wszelkie znaczenie jest względne, wszelka prawda jest nieuchwytna i dlatego pozbawiona znaczenia [...]. Dekonstruktywiści i myśliciele o podobnej umysłowości sprzyjają klimatowi, w którym ideologowie i propagandyści, na przykład tacy, którzy zaprzeczają Holokaustowi, mogą próbować zaatakować te dwa filary ludzkiej cywilizacji - pamięć i prawdę”7.

Przed nadużyciami i mieliznami intelektualnymi, które niesie ze sobą fascynacja kategorią pamięci, ostrzega Kerwin Lee Klein. Wskazuje on na dwie obecnie dyskutowane koncepcje pamięci: „terapeutyczną” (korzystającą z terminologii Freudowskiej) oraz „awangardową” (związaną z postmodernizmem). Postmodernistyczna z ducha koncepcja pamięci odkrywa w niej doświadczenie „ponownego oczarowania” i „bezpośredniego obcowania”, zastępujące „historię”, a nawet stające się jej przeciwieństwem. Zawiera w sobie to, co niewysłowione i niemożliwe

${ }^{4}$ J.-F. Lyotard, op. cit. Referuję strony: 32-33 oraz 56-58. Cytat w moim tłumaczeniu pochodzi ze s. 58 .

${ }^{5}$ Wśród koszmarnej zbrodni: notatki więźniów Sonderkommando, przekł. z jidysz i francuskiego, wybór i opracowanie rękopisów J. Bezwińska, D. Czech, wyd. II rozszerzone, Oświęcim 1975.

${ }^{6}$ P. Czapliński, op. cit., s. 14.

${ }^{7}$ Cyt. za: A. Milchman, A. Rosenberg, Eksperymenty w myśleniu o Holocauście. Auschwitz, nowoczesność i filozofia, przeł. L. Krowicki, J. Szacki, Warszawa 2003, s. 72. 
do wysłowienia. Obszar to rozległy i szczególnie ulubiony przez badaczy Zagłady wywodzących się z tej inspiracji. Tak rozumiana pamięć „odnosi się do sfery »niewypowiedzianego« - ekscesów, tabu, ciemności, rzeczy wzniosłych - lub Absolutu, którego tajniki czytelne są jedynie dla garstki wybrańców, posiadających tajemny kod dostępu. [...] Jak zauważył James Berger w swej analizie teorii traumy i jej fascynacji »dyskursem o niewypowiedzianym «, część postmodernistycznego słownika katastroficznego zdaje się ostatnio zacierać, przybierając formę »traumatyczno-świętej-wzniosłej inności«"8.

Inne groźne pułapki ponowoczesnego stylu myślenia o Zagładzie tkwią w niektórych założeniach „zwrotu narratywistycznego” w filozofii historii oraz konstruktywistycznej orientacji w badaniach humanistycznych. Chodzi tu o niebezpieczeństwo nadużyć takich kluczowych pojęć jak „źródło historyczne” czy „fakt historyczny".

Musimy sobie uświadomić - jak przypomina Jerzy Topolski ${ }^{9}$ - że samo sformułowanie „źródło historyczne” ma postać zleksykalizowanej metafory, w której nie odczuwa się już metaforyczności. Zgodnie z logiką takiego zatarcia metaforyczności należałoby powiedzieć, że ze źródła płynie coś krystalicznie czystego jak źródlana woda. Wodą, którą historyk czerpie ze źródła, jest prawda. W tym sensie źródła uzyskują poznawczo wyższy status niż powstająca na ich podstawie narracja historyczna. „To przeświadczenie, z którego wynika kategorialne odróżnianie źródeł i narracji historycznej i traktowanie źródeł jako depozytariuszy prawdy, nazywam mitem źródeł historycznych”, pisze Topolski ${ }^{10}$. Autor przytacza dwa przejawy mitu źródeł. Jeden - to należąca do warsztatowego kanonu reguła, która rodzi przeświadczenie, że posiadanie dwóch niezależnych źródeł potwierdzających wzajemnie informacje o tym samym fakcie praktycznie rozstrzyga o jego prawdziwości. W wątpliwość można tu podać zarówno samą zasadę dwóch źródeł (czy informacja z jednego źródła musi być a priori niewiarygodna?), jak i pojęcie ich niezależności, źródła mogły bowiem powstać niezależnie od siebie, ale ich autorzy mogli być zależni np. od wspólnej wizji świata. Drugi przejaw mitu źródeł to przeświadczenie, że im więcej źródeł, tym historyk jest bliżej prawdy. Jednakże wartość poznawcza źródeł nie może być ustalana a priori, lecz jedynie w stosunku do konkretnego badania, inaczej mówiąc - w odniesieniu do tego, czego historyk szuka.

W pozytywistycznie zorientowanej metodologii historii przedmiotem badań jest fakt historyczny, czyli określone zdarzenie, które miało miejsce w przeszłości, a zadaniem historyka jest bezsporne ustalenie tych faktów. W samym pojęciu faktu historycznego kryje się jednak niewypowiedziane wprost przeświadczenie, że po pierwsze - to, co zostało ustalone i nazwane faktem, rzeczywiście kiedyś zaistniało;

${ }^{8}$ K.L. Klein, O pojawieniu się pamięci $w$ dyskursie historycznym, przeł. M. Bańkowski, „Konteksty. Antropologia kultury - etnografia - sztuka”, 2003, nr 3-4, s. 48.

${ }^{9}$ Zob. J. Topolski, Jak się pisze i rozumie historię. Tajemnice narracji historycznej, Warszawa 1996 (zob. poświęcony tym zagadnieniom rozdział XX: Źródła historyczne a narracja historyczna, s. 335-348).

${ }^{10}$ J. Topolski, op. cit., s. 337. 
po drugie - że przysługuje mu status rzeczywistości autonomicznej, niezależnej i oddzielonej zarówno od procesu poznania, jak i podmiotu poznającego. Tymczasem od czasu przełomu antypozytywistycznego w humanistyce akceptuje się czynną rolę podmiotu w konstytuowaniu przedmiotu badań. Fakt historyczny nie jest zatem jakąś „rzeczą samą w sobie”, lecz konstrukcją tworzoną przez historyka na podstawie szeregu informacji pośrednich, które musi zinterpretować i dokonać ich strukturalizacji. Fakt historyczny jest konstrukcją, bowiem to historyk wskazuje na pewne zjawiska, zakreśla ich chronologiczne, geograficzne i rzeczowe granice, porządkuje, nadaje im sekwencyjny charakter czy porządek przyczynowo-skutkowy. „Faktów nazwanych tu »fizycznymi« [czyli „dostarczanych przez naturę”, jak np. śmierć człowieka - J. L.] źródła historyczne przekazują nam nieskończoną ilość. Historyk umiejscawia je w społeczeństwie, posługując się świadomą lub nieświadomą o nim wiedzą. Grupując je, wydzielając, wyizolowując, łącząc - historyk konstruuje z nich to, co potocznie nazywamy »faktami historycznymi«"- pisze Witold Kula ${ }^{11}$.

Na dwa przykłady nadużyć ponowoczesnej praktyki naukowej dotyczącej studiów nad Zagładą wskazuje Joanna Tokarska-Bakir ${ }^{12}$. Jeden odnosi się do granic wolności interpretacji „faktów”, drugi do patologii relacji między dyskursem a rzeczywistością. Christopher Browning, jeden z najwybitniejszych historyków Zagłady, mistrz gromadzenia faktów odsłaniających z niebywałą precyzją modus operan$d i$ „ostatecznego rozwiązania”, pisze: „101 Rezerwowy Batalion Policji przybył do Józefowa rankiem 13 VII 1942 i rozstrzelał wiele setek Żydów w pobliskim lesie. Takie »fakty« po prostu nie pozwalają na interpretację, nie mają żadnego sensu, przynajmniej w tych kategoriach pytań o sens, na które ja poszukuję odpowiedzi”"13. Tokarska-Bakir komentuje: „Choć odkrycie wszechobecności interpretacji było kiedyś przełomem, dziś odkrywcze jest raczej pytanie, jak to się dzieje, że niektóre fakty tak dobrze się bez interpretacji obywają. Interpretacja nigdy nie jest niewinna i nie zawsze jest potrzebna, szczególnie zaś nie jest niewinna wtedy, gdy nie jest potrzebna"14.

Drugi przykład pochodzi z wypowiedzi francuskiego historyka Pierre’a Vidal-Naqueta. Ten subtelny znawca starożytnej Grecji zajmował się także historią współczesną, zbrodniami kolonializmu, potępiał tortury stosowane przez Francuzów w Algierii, zwalczał również postawy negacjonistyczne: zaprzeczanie zarówno ludobójstwu Ormian dokonanemu przez Turków, jak i Zagładzie Żydów dokonanej przez Niemców. Bronił rzeczywistości przeciwko pokusom jej zamazywania, maskowania, rozmywania. Doskonale świadomy tego, że historia jawi się nam poprzez dyskurs o historii, zaznaczał jednak, że „jest coś, co istnieje poza nim, co było

${ }^{11}$ W. Kula, Rozważania o historii [w:] idem, Wobec historii, Warszawa 1988, s. 42-44.

12 Zob. J. Tokarska-Bakir, Syn marnotrawny dziesięć lat później, „Teksty Drugie” 2005, nr 4, s. 145-147.

${ }^{13}$ Cyt. za: J. Tokarska-Bakir, op. cit., s. 146.

${ }^{14}$ Ibidem, s. 147. 
przed nim, coś, czego w żaden sposób nie można sprowadzić do dyskursu, i co nadal byłbym skłonny nazywać rzeczywistością"15.

Wszelkie przedstawienia Zagłady w sztuce stają wobec - z grubsza rzecz biorąc - dwóch zagrożeń. Wyobraźmy sobie rwącą rzekę albo głęboką przepaść. Przeszkody nie do pokonania. Ponad nimi zawieszona jest wąska, chwiejna, niepewna kładka rozpięta między obydwoma brzegami i wsparta na stałym gruncie. Wszystko zależy od trwałości tego podłoża. Jeśli zaczepienie jest solidne, grunt twardy - jest szansa, aby przejść ponad przepaścią, ponad wodą. Ale jeśli oba brzegi zbudowane są tylko z lotnych piasków, niedających pewnego oparcia, niepozwalających na założenie fundamentów? Co stanie się z kładką, kiedy na nią wstąpimy? Otóż sądzę, że przedstawienia Zagłady, niczym owa kładka nad przepaścią, rozpięte są między biegunem trywializacji i kiczu z jednej strony a biegunem sublimacji i sakralizacji z drugiej strony. I w jednym, i w drugim przypadku doświadczenie Zagłady zostaje wypchnięte poza obszar tego, co realne.

Wydaje się, że dyskurs akademicki o Zagładzie stoi wobec potężnej pokusy, której doprawdy trudno się oprzeć. Nazwałbym ją pokusą narcyzmu. Artyści są narcystyczni. Jest to nie tylko zrozumiałe i usprawiedliwione, lecz także powszechnie przyjęte, wręcz oczywiste. Przeświadczenie, że rys narcystyczny naznacza głęboko także osobowość badaczy, ludzi nauki, akademików - jest już mniej oczywiste. Być może dlatego, że bardziej skrywane.

Potraktujmy Fabrykę muchołapek Andrzeja Barta ${ }^{16}$ jako ogniwo pośrednie pomiędzy przedstawieniem Zagłady w sztuce i w nauce. Autor odbywa rozległe studia holokaustowe, starannie przygotowuje materiał źródłowy, bada dzieje getta łódzkiego i swego powieściowego bohatera Chaima Rumkowskiego. Wszystko po to, aby rozpostarłszy przed czytelnikiem tęczę całej swojej erudycji i kunsztu literackiego, wykreować quasi-świat quasi-sądu nad quasi-Rumkowskim. Konstrukcja ta utkana jest z cytatów i quasi-cytatów źródłowych, postacie historyczne wypowiadają się własnym bądź prawie własnym głosem, wszystko (prawie) się zgadza. Tylko że „prawie” robi wielką różnicę. Książka Barta jest dla mnie przykładem kiczu narcystycznego. Jest w pół drogi między literaturą a dokumentem, powieścią a relacją, zeznaniem a zapisem snu. Jest manifestacyjnie „pomiędzy” dyskursami, gatunkami, prawdą a zmyśleniem. W stu procentach spełnia zatem model postliteratury w czasach postnowoczesnych. Niczym więc nie zaskakuje - jej poetyka jest doskonale przewidywalna, aż do bólu „posttradycyjna”. Schlebia gustom i modom, które są trendy. Jest także poznawczo doskonale pusta. Bawi się konwencjami mówienia, przytoczeniami, perspektywami narracyjnymi, pomysłami fabularnymi, ale do niczego to nie prowadzi. Mówiąc precyzyjniej: nie prowadzi do niczego poza za-

\footnotetext{
${ }^{15}$ Ibidem, s. 146.

${ }^{16}$ Zob. recenzję Justyny Kowalskiej-Leder w tym numerze.
} 
spokojeniem ego samego autora. Po przeczytaniu Fabryki muchołapek wiemy tyle samo o dylematach Rumkowskiego i o doświadczeniu Zagłady, ile wiedzieliśmy przed lekturą. Staliśmy się jedynie zakładnikami erudycyjnych i literackich popisów Andrzeja Barta. Czysty narcyzm.

Do narcystycznych nadużyć w obszarze naukowo zorientowanych tekstów o Zagładzie zaliczyłbym dające się dość łatwo zauważyć przejawy wybujałej emocjonalności. Zdarza się, że autor świadomie łamie zasadę neutralności języka czy regułę powściągliwości, rzeczowości, klarowności pojęć i zrozumiałości stosowanych terminów. Dominantą tekstu staje się nie tyle porządek merytoryczny, ile intensywność ekspresji. Tak jakby wartości poznawcze schodziły na dalszy plan, ustępując miejsca efektom poetyckim. Tekst prezentuje wszem wobec swoją retoryczność, tak jakby to właśnie rozwinięcie kunsztownej retorycznej konstrukcji było ostatecznym celem autora, a Zagłada stawała się tylko kanwą dla misternych splotów metafor i lirycznych inkantacji. W takim modelu naukowego narcyzmu autorskie JA dominuje, zasłaniając rzeczywistość Zagłady. Autorskie JA zdaje się wypełniać sobą wszystko. Jest wszędzie obecne: w układzie zdań, w ich poszarpanym, fragmentarycznym toku, pełnym wykrzyknień, pytań retorycznych, w zderzeniach długich, wypełnionych przymiotnikami okresów i pojedynczych słów.

Sądzę, że przykładem tego typu „postnaukowego” narcyzmu jest, skądinąd niezwykle ciekawy, inspirujący i stawiający bardzo ważne pytania tekst Piotra Weisera o akcji „Erntefest” widzianej oczami polskich więźniów Majdanka ${ }^{17}$. To oparte na rozległym materiale źródłowym studium rozdarte jest przez dwa żywioły - badawczy i liryczny. Wydaje się, że autorowi czasem trudno zdecydować, czym ma być jego tekst: rozprawą poddaną nawet bardzo liberalnie i ponowocześnie rozumianym rygorom dyskursu naukowego czy też osobistą medytacją. W wielu miejscach nad racjonalnością górę bierze emocjonalność i impresyjność, a tok analityczny zakłócany jest rytmem aleatorycznym, wariacyjnym, skojarzeniowym. Krzyżują się ze sobą wszystkie trzy formy podawcze: mowa niezależna (przytoczenie integralnego cytatu), mowa zależna (zrelacjonowanie cudzych słów) oraz mowa pozornie zależna (forma wyraźnie dwugłosowa, gdzie słowo cudze i słowo własne są zmieszane). Zacytujmy dłuższy fragment: „Infernum w tekstach Polaków nie brzmiało jak metafora w wersetach Dantego. Rozżarzone krematorium przypominało piekło na ludzkiej ziemi, rozpasany funkcjonariusz uosabiał szatana w ludzkiej postaci. Skojarzenia eschatologiczne są powtarzane najczęściej: »jeżeli kiedykolwiek ma być koniec świata, to ja już go wówczas wraz z wielu innymi przeżyłem«. [...] Europę spowijały masowe mordy. Jesienna zbrodnia podsuwała zaś hierarchię wszystkich potworności. Taka »potworna zbrodnia« w »dziejach ludzkości« była »rzadko notowana«. Świadkowie nie prowadzą akademickich dyskusji nad wyjątkowością. Znajdowane precedensy tylko uzasadniały potworność. Gimnazjalista wymienił takie wydarze-

${ }^{17}$ P. Weiser, „Poszli wszyscy: mężczyźni, kobiety, starcy i maleńkie dzieci. Poszli na zagładę”. „Erntefest” zmystami polskich więźniów Majdanka [w:] 3-4 listopada 1943. Erntefest - zapomniany epizod Zagłady, red. W. Lenarczyk, D. Libionka, Lublin 2009, s. 105-152.. 
nia. »Rzeź Kartaginy, najazd Hunów, upadek Jerozolimy«. Natomiast ta zbrodnia to »dzień, który winien przejść do historii w randze takich wydarzeń«. Zdanie to musiało brzmieć sugestywnie, przepisał je bowiem któryś współwięzień.

Uczestnictwo w apokalipsie przekształca przerażenie w egzaltację. Wiekopomne zdarzenie przydaje znaczenia obserwatorowi. Zajrzał do piekła! Kto jeszcze może o sobie tak powiedzieć? Uzbrojony w przewodnik turysta w Kartaginie wspomina wojny Hannibala; pogrążony w modlitwie pielgrzym w Jeruzalem odczytuje strofy Jeremiasza. Spoglądają przez okna tradycji. Tamten pisze osobiście. Był tam. Widział to, jeżeli nie wszystko, to niemało. Zdradza go błysk w oku, gdy stoi w oku cyklonu. Dostrzega dym pogorzeliska z lekkim syndromem piromana. Egzaltacji grozi ekscytacja. Pokusie raczej nie ulega, choć notuje jej obecność. Również takie ślady niesie jego opowieść"18.

Idąc tropem podsuniętym przez samego autora, można pokusić się o wskazanie mocnych punktów swoistej trajektorii „postnaukowego” dyskursu holokaustowego z dominantą emocjonalną: estetyzacja - egzaltacja - ekscytacja.

Do innego rodzaju nadużyć prowadzi wybujała erudycyjność, wykarmiona na narcystycznej pożywce i pleniąca się bujnie, szczególnie w tekstach uczniów, naśladowców i epigonów postmodernistycznego dyskursu. Ten sposób pisania zdaje się obejmować coraz większe obszary refleksji o Holokauście. Do szczególnie hołubionych słów kluczy (a może raczej: słów wytrychów) należą takie jak: niewyrażalność, aporia sensu, milczenie, pustka, nieobecność etc. - pojęcia kluczowe dla refleksji o Zagładzie, ale przez ich zrytualizowane użycia pozbawione już większego sensu, poza czysto liturgiczną funkcją przytoczenia i powtórzenia. Sygnalizują przynależność do pewnego środowiska i - niczym żargon złodziejski - tworzą ekskluzywną wspólnotę, wykluczając innych z komunikacji ${ }^{19}$. Mówienie o niemożliwości mówienia o Holokauście, monotonnie powtarzane za wielkimi mistrzami ponowoczesności, staje się coraz bardziej jałowe, bo coraz bardziej przewidywalne, jak powielany do znudzenia dekoracyjny ornament.

Przykładem takiej narcystyczno-liturgicznej erudycyjności jest dla mnie pretensjonalny i bełkotliwy wstęp Jana Goślickiego do znakomitej książki-świadectwa Zagłady pióra Piotra Rawicza Krew nieba ${ }^{20}$. Zacytujmy fragment: „Ustanowiona tu zostaje sygnifikacja destabilizująca, w której pomiędzy język i świat pada cień Wielkiej Niepoświadczonej Jatki. Mówisz »krzesło«, ale do słowa dołącza się obraz rozłupanej przez bombę ściany i odsłoniętego kąta pokoju, w którym to ocalone (ocalone? O-calone?) krzesło stoi. A co »znaczy«? »Krzesło«? »Krzesłowatość«? »Negacje krzesła«? Pusty znak? W jakiś sposób wszystko to naraz, jedno odsyła do

${ }^{18}$ Ibidem, s. 117-118.

${ }^{19} \mathrm{O}$ wykluczającej funkcji żargonów złodziejskich pisał Bronisław Geremek: „Sam fakt poszukiwania tajemnego kodu porozumienia pozwalał grupę taką traktować jako przestępczą. Łącząc jednych i wyłączając innych z porozumienia, żargon żyje i funkcjonuje w ramach napięć i konfliktów między społeczeństwem zorganizowanym a grupami marginalnymi”. O językach tajemnych, „Teksty” 1980, nr 2, s. 15-16.

${ }^{20}$ Piotr Rawicz, Krew nieba, przeł. A. Socha, Kraków 2003. 
drugiego, odwlekając w nieskończoność odpowiedź definitywną. Otóż Rawicz czyni wrażenie kogoś, kto znajduje się w posiadaniu słownika, którego hasła są tak właśnie skonstruowane i który konsekwentnie się nimi posługuje.

Jeśli taki język »po Zagładzie«, przyjmując nicość za centrum sygnifikacji, wyrzeka się argumentu, prezentacji, narracji, jeśli odsyła do różnicy, każdy z której członów równie dobrze daje się pomyśleć [sic! - J. L.], (»Psalm« to teologia i ontologia, ale duch nowoczesny, od zdecydowanie anty-teologicznego Gombrowicza, do radykalnie anty-teologicznego Derridy, sproblematyzować zdążył wszystko - "prawdę«, »istotę«, "początek«, »koniec«, »wewnątrz «, »zewnątrz « itd. umieszczając sens w różnicy - a jest to sens odwleczony, zakładający nieskończoność relacji, nieostateczny), to przynajmniej nie nadaje się on do przewodzenia najróżniejszych głupawych ideologii, ponieważ, pozostając w nim, niepodobna mieć racji”21.

Ten wytrawny eseista i tłumacz, który ukrywał się w czasie okupacji wraz z rodzicami na krakowskim Kazimierzu, był uczniem Paula de Mana. Wie zatem dobrze, o czym pisze. Ale czy czytelnik jest w stanie podążać za meandrami jego myśli i przebić się przez enigmatyczność jej wysłowienia? Nie mogę oprzeć się wrażeniu, że wstęp do książki Rawicza znakomicie oddaje całą jałowość i wtórność przejętego od mistrzów języka.

O co zatem chodzi w naukowych dociekaniach nad Zagładą? Czy wolno nam dać się ponieść fali i płynąć z wdziękiem po gładkiej tafli wody, która odbijać będzie nasze zadowolone $z$ siebie oblicza? Odpowiem naiwnie i po staroświecku: chodzi o to, co się rzeczywiście wydarzyło, i o drugiego człowieka. O tych, którzy zostali zgładzeni, a każdy z nich miał swoją własną twarz i swoje imię.

Nie jestem jednak aż tak naiwny, by snuć nostalgiczne marzenia o pierwotnym ładzie i harmonii między słowem i bytem, między prawdą a rzeczywistością, między światem a językiem. Wiem, że żyjemy w czasach kryzysu tradycyjnie pojętego doświadczenia, które zmienia swą naturę: „odkleja się” od realności, traci spójność i poznawczą neutralność, rozwarstwia się. Między tym, co przedstawione, a samym przedmiotem jest jakaś niepokojąca, trudna do przebycia przestrzeń ${ }^{22}$. Doskonale zdaję sobie sprawę, że - pożyczając sformułowanie od George’a Steinera - „kontrakt został zerwany"23.

Posłuchajmy Steinera: „Wszystko można powiedzieć i w konsekwencji także napisać o wszystkim. Rzadko przystajemy, by zauważyć czy skonstatować tę

${ }^{21}$ Ibidem, s. $13-14$.

${ }^{22}$ Odwołuję się tu do tez Ryszarda Nycza, sytuującego tradycyjne koncepcje doświadczenia wobec form nowoczesnego doświadczenia. Zob. Literatura nowoczesna wobec doświadczenia [w:] Literackie reprezentacje doświadczenia, red. W. Bolecki, E. Nawrocka, Warszawa 2007.

${ }^{23}$ Odwołuję się tu do eseju pt. Zerwany kontrakt, w: G. Steiner, Rzeczywiste obecności, przeł. O. Kubińska, Warszawa 1989. 
oczywistość. Jednakże przepełnia ją jakaś tajemnicza monstrualność”24. Dalej czytamy: „Możemy wypowiedzieć wszelką prawdę i każdy fałsz. [...] Mówienie - czy to do siebie, czy do kogoś innego - oznacza, w najbardziej obnażonym, rygorystycznym znaczeniu tej niewyobrażalnej banalności, wymyślanie po raz wtóry istnienia i świata"25.

Steiner kreśli panoramę kultury, sztuki, refleksji humanistycznej, w której doszło do zerwania przymierza między słowem a światem. Jest to, twierdzi eseista, jedna z niewielu rewolucji ducha w historii Zachodu, która w zasadniczy sposób określa naszą współczesność. Jesteśmy w fazie post-Logosu. W fazie ponowoczesności. Staroświecki termin „znaczenie” trzeba zastąić „nieskończoną sygnifikacją” otwierającą „nieskończone możliwości”, albo też „podążaniem śladami”. Zacytujmy konkluzję eseju George’a Steinera: „Musimy zapytać siebie i naszą kulturę, czy świecki, zasadniczo pozytywistyczny, model rozumienia i doświadczenia znaczącej formy (estetyka) jest możliwy do utrzymania w świetle, czy - jeśli ktoś woli w ciemności nihilistycznej alternatywy. [...] Całkiem możliwe, że na te pytania nie można już znaleźć dojrzałej, nie mówiąc o pocieszającej, odpowiedzi. Mogą być jedynie wykwitami nostalgii i patosu. Najokrutniejszy z paradoksów w dekonstrukcji brzmi następująco: nie było żadnego miejsca startu, lecz istnieje, w odniesieniu do naszego niewinnego, pozornego, oportunistycznego przemieszkiwania w znaczeniu, miejsce, w którym może nastąpić koniec. Wydaje się jasne, że tego wyzwania nie można uniknąć. [...] Obecnym mistrzom pustki chodzi o zabawę. I tym się właśnie różnimy”26.

Rozum dociekający prawdy nie zna granic. W odwiecznym ruchu poszukiwania, wątpienia, pytania, kwestionowania jest wolny. Nie zna spoczynku i nie boi się ryzyka. Skąd wiadomo, kiedy się myli, kiedy błądzi po manowcach? Steiner podsuwa niepewne kryterium, ale cóż jest pewnego na tym świecie. Jeśli mistrzom pustki chodzi tylko o zabawę, o zaspokojenie narcystycznych pokus - nie będę z nimi.

\section{Słowa kluczowe}

badania nad Zagładą Żydów, postmodernistyczny dyskurs o Zagładzie, zagrożenia i nadużycia w badaniach naukowych
Abstract

\footnotetext{
${ }^{24}$ Ibidem, s. 47.

${ }^{25}$ Ibidem, s. 49.

${ }^{26}$ Ibidem, s. 112.
}

Abuses in art, film and literature portraying the Holocaust have finally been discussed in modern human studies. The analyses show, among others, the phenomenon of the McDonaldization of the Holocaust, its political intrumentalization, ideological manipulation and commercialization. The article tries to look critically at a different dimension of the phenomenon, hitherto undiscussed, namely the 
abuses in Holocaust research. The author identifies several dangers which appear in academic discourse about the Holocaust - from "the myth of sources" to narcissistic temptations.

\section{Key words}

Holocaust, postmodern Holocaust discourse, dangers threats and abuses in scientific research 